\title{
History of Education Society 2005 Henry Barnard Prize
}

The History of Education Society has selected the essay by Karen Leroux of Northwestern University, "Lady Teachers' and the Genteel Roots of Teacher Organization in Gilded Age Cities," to receive the Henry Barnard Prize. This prize is awarded biennially for the best essay written by a graduate student.

The award comes with an honorarium of $\$ 500$, presented at the Society's annual meeting banquet. The winner is invited to publish the essay in the History of Education Quarterly and to present the paper at the 2005 annual meeting.

The Society also recognizes for Honorable Mention the essay by Diana C. D'Amico of New York University, "A Brave New Breed of Teacher': The UFT and the Masculinization of the Teaching Profession, 1961-1964."

Members of the selection committee were Jim Carl (chair), Ken Gold, Katherine Kennedy, and Peter Wallenstein. The History of Education Society thanks them for their careful work in reading and considering the fifteen papers that were nominated. 